\title{
The 4.2 ka event, ENSO, and coral reef development
}

\author{
Lauren T. Toth ${ }^{1}$ and Richard B. Aronson ${ }^{2}$ \\ ${ }^{1}$ US Geological Survey, St. Petersburg Coastal and Marine Science Center, St. Petersburg, FL 33701, USA \\ ${ }^{2}$ Department of Ocean Engineering and Marine Sciences, Florida Institute of Technology, Melbourne, FL 32901, USA
}

Correspondence: Lauren T. Toth (ltoth@usgs.gov)

Received: 31 July 2018 - Discussion started: 31 August 2018

Accepted: 13 December 2018 - Published: 16 January 2019

\begin{abstract}
Variability of sea-surface temperature related to shifts in the mode of the El Niño-Southern Oscillation (ENSO) has been implicated as a possible forcing mechanism for the global-scale changes in tropical and subtropical precipitation known as the 4.2 ka event. We review records of coral reef development and paleoceanography from the tropical eastern Pacific (TEP) to evaluate the potential impact of the $4.2 \mathrm{ka}$ event on coral reefs. Our goal is to identify the regional climatic and oceanographic drivers of a 2500-year shutdown of vertical reef accretion in the TEP after $4.2 \mathrm{ka}$. The 2500-year hiatus represents $\sim 40 \%$ of the Holocene history of reefs in the TEP and appears to have been tied to increased variability of ENSO. When ENSO variability abated approximately $1.7-1.6 \mathrm{ka}$, coral populations recovered and vertical accretion of reef framework resumed apace. There is some evidence that the $4.2 \mathrm{ka}$ event suppressed coral growth and reef accretion elsewhere in the Pacific Ocean as well. Although the ultimate causality behind the global $4.2 \mathrm{ka}$ event remains elusive, correlations between shifts in ENSO variability and the impacts of the $4.2 \mathrm{ka}$ event suggest that ENSO could have played a role in climatic changes at that time, at least in the tropical and subtropical Pacific. We outline a framework for testing hypotheses of where and under what conditions ENSO may be expected to have impacted coral reef environments around $4.2 \mathrm{ka}$. Although most studies of the $4.2 \mathrm{ka}$ event have focused on terrestrial environments, we suggest that understanding the event in marine systems may prove to be the key to deciphering its ultimate cause.
\end{abstract}

\section{Introduction}

The abrupt climatic shift at $\sim 4200$ years before present (BP; expressed as years before 1950), known as the $4.2 \mathrm{ka}$ event, is now recognized by many scientists to be the most significant climatic perturbation of the middle to late Holocene (Walker et al., 2012; ka stands for thousands of years ago). On 25 June 2018, the International Union of Geological Sciences officially subdivided the Holocene epoch, with the $4.2 \mathrm{ka}$ event marking the start of the late Holocene, or the Meghalayan age. Although the signature of the $4.2 \mathrm{ka}$ event is not as ubiquitous as the north Atlantic cooling episode known as the $8.2 \mathrm{ka}$ event, which is the demarcation between the early and middle Holocene, it is now clear that the $4.2 \mathrm{ka}$ event had global climatic, ecological, and cultural impacts (Mayewski et al., 2004; Weis, 2016). In most locations, the $4.2 \mathrm{ka}$ event manifested as extreme and abrupt changes in terrestrial hydroclimate (Staubwasser et al., 2003; Marchant and Hooghiemstra, 2004; Walker et al., 2012; Xiao et al., 2018), which drove environmental changes (Marchant and Hooghiemstra, 2004; Booth et al., 2005) and cultural collapses (Weiss et al., 1993; Staubwasser et al., 2003; Weiss, 2016; Wu et al., 2016) on a global scale. The ultimate cause(s) of the event and its impact and connection with other regional- to global-scale climatic changes remains unknown (Walker et al., 2012).

Whereas shifts in the climate of high-latitude regions in general, and the northern Atlantic in particular, have been implicated in the majority of climate events during the late Quaternary (Dansgaard et al., 1993; Mayewski et al., 2004; Booth et al., 2005; Walker et al., 2012), there is little evidence for a high-latitude driver of the $4.2 \mathrm{ka}$ event (Walker et al., 2012). The event is only weakly recorded in Greenland ice-core records (Johnsen et al., 2001; Marchant and 
Hooghiemstra, 2004; Mayewski et al., 2004; Rasmussen et al., 2006): major cooling in the northern Atlantic, and the associated onset of Northern Hemisphere neoglaciation, preceded the $4.2 \mathrm{ka}$ event by at least 1000 years (Svendsen and Mangerud, 1997; Mayewski et al., 2004; Walker et al., 2012; Marcott et al., 2013). The lack of a clear high-latitude forcing mechanism for the $4.2 \mathrm{ka}$ event has led some researchers to suggest that there may have been a tropical driver of the climatic changes around this time (Marchant and Hooghiemstra, 2004).

The most significant source of climatic variability in the tropics is the El Niño-Southern Oscillation (ENSO). Although ENSO originates in the tropical Pacific, it causes global-scale thermal anomalies and changes in hydroclimate (McPhaden et al., 2006). The climatological manifestations of individual El Niño and La Niña events can vary, but many of the broadscale impacts of ENSO are similar to the globalscale changes inferred to have taken place during the $4.2 \mathrm{ka}$ event. For example, some of the most striking changes associated with the $4.2 \mathrm{ka}$ event were apparent shifts in the strength of the Asian monsoon (Staubwasser et al., 2003; Wang et al., 2003). ENSO variability has been closely linked with the dynamics of the Asian monsoon throughout the Holocene (Liu et al., 2000). Whereas El Niño events are typically associated with a weaker monsoon and resultant drought conditions, the monsoon is stronger during La Niña events (Liu et al., 2000; Wang et al., 2003). The similarity in the climatic changes associated with ENSO and the $4.2 \mathrm{ka}$ event, coupled with the evidence for increasing ENSO variability around $4.2 \mathrm{ka}$ (Conroy et al., 2008; Koutavas and Joanides, 2012; Carré et al., 2014), has led a number of researchers to suggest that ENSO may have played a salient role in the $4.2 \mathrm{ka}$ event (e.g., Marchant and Hooghiemstra, 2004; Booth et al., 2005; Walker et al., 2012; Li et al., 2018). It is not yet clear, however, whether changing ENSO variability around $4.2 \mathrm{ka}$ is likely to have been an ultimate driver of broadscale climatic changes around this time or whether ENSO was a proximal response to other climatic forcing.

Coral reefs are excellent models for elucidating the causes and consequences of climatic excursions such as the $4.2 \mathrm{ka}$ event. Reef-building (hermatypic) corals, which secrete aragonitic skeletons that build the geologic frameworks of the reefs, are highly sensitive to extremes in temperature and light. As a result, coral reefs are among the most vulnerable ecosystems to modern anthropogenic climate change (e.g., Hoegh-Guldberg, 1999; Hughes et al., 2018). Photosynthetic dinoflagellates, called zooxanthellae, which live endosymbiotically within the cnidarian hosts, provide the animal component of the coral holobiont (the entire animal-plantmicrobial symbiosis) with nearly all of its energetic needs (Muscatine and Porter, 1977). Persistently high temperature and light levels, which are now occurring with increasing frequency as a result of anthropogenically driven climate change, disrupt the mutualistic relationship between the coral animal and the zooxanthellae, leading to coral bleaching and

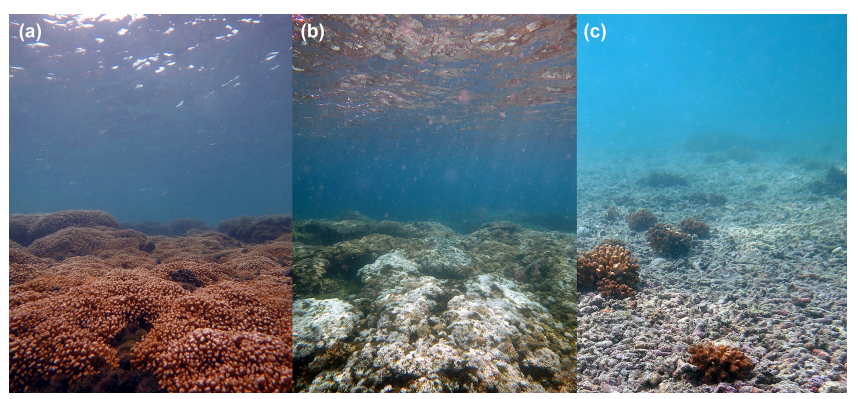

Figure 1. Photographs depicting the typical states of coral reefs in Pacific Panama (a) before, (b) during, and (c) after an El Niño event. Photograph (a) shows an example of a well developed coral reef dominated by branching Pocillopora corals. Photograph (b) shows a reef dominated by Pocillopora experiencing high levels of coral bleaching during the 2015-2016 El Niño event. Photograph (c) shows a large area of Pocillopora rubble that has persisted since the 1982-1983 El Niño event.

associated morbidity and mortality (Fig. 1; Brown, 1987; Glynn, 1991; Hoegh-Guldberg, 1999; Donner et al., 2005; Anthony, 2016; and many others). Cold-water conditions are also inimical to coral growth and reef development (Ginsburg and Shinn, 1994; Precht and Aronson, 2004; Lirman et al., 2011; Kemp et al., 2016; Toth et al., 2018). Corals are vulnerable to a variety of other stresses and disturbances, including sedimentation, subaerial exposure, nutrient loading, hurricane damage, low-pH conditions, and low salinity (Kleypas et al., 1999; Aronson and Precht, 2001; Buddemeier et al., 2004; Goldberg, 2013), which can increase as a result of (or in tandem with) climatic shifts in one direction or another. Reef frameworks and the coral skeletons that constitute them preserve well in the fossil and subfossil record, providing a historical record of the response of coral reefs to climate change (Jackson, 1992). Moreover, many of the perturbations listed above leave geochemical and taphonomic traces that can be used as proxies to reconstruct changes in environmental conditions (e.g., Cobb et al., 2013; Toth et al., 2012, 2015a, b; Flannery et al., 2018).

Whereas the majority of the records of the $4.2 \mathrm{ka}$ event have come from terrestrial environments, the contemporary impacts of ENSO are often felt most keenly in marine ecosystems. Understanding whether and how marine ecosystems responded to climatic changes around $4.2 \mathrm{ka}$ is, therefore, critical to discovering the ultimate drivers of the $4.2 \mathrm{ka}$ event. Here, we explore the hypothesis that ENSO played a role in the $4.2 \mathrm{ka}$ event by reviewing paleoecological and paleoceanographic records from marine environments in the tropical Pacific. We focus on the long-term collapse of coral reef development in the tropical eastern Pacific (TEP), which appears to be related to changes in ENSO. We conclude that the relationship between ENSO and the $4.2 \mathrm{ka}$ event warrants further study and we outline a conceptual framework for future studies to investigate the linkages between these climatic 
phenomena using records from coral reef environments in the tropical Pacific.

\section{Climate and coral reef development in the tropical eastern Pacific (TEP)}

\subsection{Ecology of coral reefs in the TEP}

Holocene reefs of the TEP are, for the most part, small and poorly developed, as is generally the case for reefs on the eastern margins of ocean basins (Darwin, 1862; Cortés, 1993). Regional and local diversities of hard corals are low in the TEP. Several living reefs, however, overlie well developed Holocene frameworks that preserve millennial-scale records of regional and larger-scale climatic variability, and the responses of coral assemblages to that variability.

The shallowest habitats of contemporary reefs off the Pacific coast of Panama, ranging from 1 to $5 \mathrm{~m}$ water depth, are characterized by fields of branching corals of the genus Pocillopora (Fig. 1a; Glynn and Macintyre, 1977; Cortés, 1997; Glynn and Ault, 2000). The stands of Pocillopora are dominated by what has been termed $P$. damicornis, but they include several other species in the genus (many or most of which are hybrids; see below). Massive corals, primarily Pavona spp., Porites spp., and Gardineroceris planulata, become more abundant with increasing depth below the zone of essentially monogeneric occupation by Pocillopora (Glynn, 1976; Glynn and Maté, 1997).

Richmond $(1987,1990)$ suggested that $P$. damicornis in the TEP had adopted a life history strategy of exclusive, or nearly exclusive, asexual reproduction. In this scenario, the populations were seeded by sexually produced planula larvae from the central Pacific, which were transported by the North Equatorial Countercurrent and by eastward equatorial flow during El Niño conditions (Glynn and Ault, 2000). Oceanographic modeling exercises, however, cast doubt on Richmond's proposed teleconnection between the central and eastern Pacific, at least so far as Pocillopora is concerned (Wood et al., 2016; Romero-Torres et al., 2018). Furthermore, genetic analysis by Combosch et al. (2008) demonstrated that the eastern Pacific populations of Pocillopora reproduce sexually. The genetics showed a difference in reproductive strategy in the genus Pocillopora between the eastern Pacific and the rest of its range in the Indo-Pacific: Pocillopora reproduce sexually by broadcast spawning in the eastern Pacific, whereas they brood internally fertilized or parthenogenetic eggs in the central and western Pacific, and in the Indian Ocean.

Broadcast spawning is correlated with interspecific hybridization among the species of Pocillopora in the TEP. Hybridization in the TEP is in turn associated with a radically different functional ecology of (hybridized) P. damicornis in the eastern Pacific, including a far more robust skeletal morphology, ecological dominance, and the construction of reef frameworks predominantly composed of Pocillo- pora branches. Within the eastern Pacific, limited gene flow among populations of (hybridized) P. damicornis (henceforth simply "Pocillopora") raises the possibility of adaptation to regional-scale oceanographic gradients of upwelling (Combosch and Vollmer, 2011).

\subsection{Response to ENSO events}

Contemporary populations of corals on reefs of the TEP (see Fig. 6.1 in Toth et al., 2017, for a map of locations where coral reefs occur) highlight the responses of coral populations to sequential perturbations by ENSO. The 1982-1983 El Niño was one of the strongest to affect the eastern Pacific in recent history (Glynn, 1988a; Glynn et al., 2001). (However, the impacts of this event were less severe elsewhere in the tropical Pacific.) Persistently elevated water temperatures for 14 months resulted in severe regional-scale bleaching of corals (Fig. 1b) and other cnidarians bearing endosymbiotic algae (Wellington and Glynn, 2007). Coral mortality ranged from $50 \%$ in Costa Rica to $97 \%$ in the Galápagos Islands and correlated with the degree of thermal stress the reefs experienced in each location (Glynn, 1990). Mortality levels were somewhat lower off the Pacific coast of Panama. In the Gulf of Panama, where seasonal upwelling is strong, coral mortality was $85 \%$. In the adjacent Gulf of Chiriquí, where seasonal upwelling is weak or absent, mortality was similar, averaging $76 \%$ (Glynn, 1990, 1991; Glynn and Colgan, 1992; Wellington and Glynn, 2007). The similarity in the level of mortality throughout Pacific Panama reflects the fact that El Niño suppressed seasonal upwelling in the Gulf of Panama in 1982-1983 so the level of warming was similar in both gulfs (Glynn et al., 2001).

Ecological observations prior to 1982 suggested that dense stands of Pocillopora had persisted throughout the TEP for decades at least. Pocillopora had in fact been the dominant benthic component in shallow reef habitats prior to the 19821983 event, covering up to $90 \%$ of the available substratum at $3-5 \mathrm{~m}$ depth (Fig. 1a). Pocillopora proved especially vulnerable to bleaching-induced mortality and vast fields were killed, although mortality was variable on multiple spatial scales (Glynn, 1990; Macintyre and Glynn, 1990). A collateral effect of Pocillopora mortality was the decline of symbiotic crustaceans that defend the corals against attack by the predatory crown-of-thorns starfish, Acanthaster planci. At Uva Island, in the Gulf of Chiriquí, Acanthaster were able to crawl across freshly killed thickets of Pocillopora to attack and kill massive corals that had not bleached as severely and did not harbor the crustaceans (Glynn, 1985, 1990). Acanthaster did not then and does not now occur in the Gulf of Panama (Glynn, 2004).

Algal turfs growing on the dead-coral surfaces led to enhanced populations of regular echinoids by increasing their food supplies. Higher densities of grazing sea urchins greatly increased bioerosion and suppressed coral recruitment, resulting in a switch from net vertical reef accretion 
to net framework erosion (Glynn, 1988a, b, 1990; Glynn and Colgan 1992; Eakin, 1996; Reaka-Kudla et al., 1996). Centennial-scale increases in the frequency of severe ENSO events such as the one in 1982-1983 could have been responsible for the poor development of reefs observed in many areas of the eastern Pacific (Glynn and Colgan, 1992; Glynn, 2000).

A second extreme ENSO event killed an estimated $16 \%$ of corals worldwide in 1997-1998 (Wilkinson, 2000). The 1997-1998 and 1982-1983 events were of approximately equal magnitude and duration in the eastern Pacific. Both events may have been enhanced by global warming and they were the two most intense events in the preceding 50 years (Hansen et al., 1999; Karl et al., 2000; Enfield, 2001; Hughes et al., 2018).

Coral mortality in the eastern Pacific was lower in 19971998 (Guzmán and Cortés, 2001; Vargas-Ángel et al., 2001). There was essentially no mortality in the Gulf of Panama because, whereas seasonal upwelling was suppressed during the 1982-1983 El Niño event, upwelling was unaltered in 1997-1998 and cooled the water column (Riegl and Piller, 2003; Glynn et al., 2001). Muted levels of coral mortality elsewhere, including only $13 \%$ mortality in the Gulf of Chiriquí, were correlated with the presence of thermally resistant zooxanthellae in the corals (Glynn et al., 2001; Baker et al., 2004; see also D'Croz and Maté, 2004). Collateral effects following the 1982-1983 event, particularly enhanced predation by Acanthaster (in the Gulf of Chiriquí) and increased bioerosion by sea urchins, were also far less severe after the 1997-1998 ENSO, due to precipitous declines of both taxa (Eakin, 2001; Glynn et al., 2001; see also Fong and Glynn, 2001). The effects of the 2015-2016 El Niño event were also minimal in Pacific Panama. Upwelling again buffered the reefs in the Gulf of Panama from elevated temperatures, and most reefs in the Gulf of Chiriquí experienced coral bleaching, but only minor bleaching-related mortality.

Coral populations have recovered to varying degrees from the El Niño events in 1982-1983 and 1997-1998, apparently having been seeded by populations that persisted within refugia in the eastern Pacific (Wood et al., 2016). Coral cover declined in the Gulf of Chiriquí at 3-7 m depth after 1983. By 2002 , coral cover was $12 \%$ at Uva Island (down significantly from $35 \%$ ) and $8 \%$ at Secas Island (down nonsignificantly from $11 \%$; Wellington and Glynn, 2007). Coral cover at Saboga Island in the Gulf of Panama recovered at 2-3 m depth from $0 \%$ in 1984 to the pre-ENSO level of $50 \%$ by 1992 . At $3-5 \mathrm{~m}$ depth, some areas of the Saboga reef recovered to $50 \%$ within a few years, but large areas of coral rubble have persisted to this day (Fig. 1c), and this has also been the case on many other reefs. The areas of coral rubble consist primarily of taphonomically degraded Pocillopora branches, which are covered in algal turfs, encrusted by coralline algae, and colonized at low frequency by the early successional coral Psammocora stellata.
In summary, elevated water temperatures and high irradiance (resulting from low cloud cover) associated with the strong El Niño events in 1982-1983 and 1997-1998 in Pacific Panama caused widespread coral bleaching, which was associated with mass coral mortality in the earlier event (Glynn et al., 2001). La Niña is also problematic for corals in Pacific Panama. Lowered sea level in the TEP during La Niña events causes more frequent coral mortality associated with subaerial exposure (Eakin and Glynn, 1996; Toth et al., 2017). In addition, La Niña is associated with elevated rainfall and enhanced upwelling in Pacific Panama. Elevated rainfall increases turbidity, and enhanced upwelling reduces water temperatures, decreases $\mathrm{pH}$, and increases nutrient levels. All of these changes act to suppress coral growth (Glynn, 1976).

Food webs on eastern Pacific reefs are complex despite their low diversity (Glynn, 2004). Corallivores other than Acanthaster, including pufferfish (Tetraodontidae) and gastropods (Pediculariidae and Muricidae), have effects that vary on multiple scales. On the other hand, because it is situated close to the Equator, Panama has not experienced a hurricane since at least as early as 1871 (Neumann et al., 1999), removing hurricanes as a factor - but not storms and wave action in the winter dry season.

\subsection{The question of prior occurrence}

The TEP has been affected by more than 30 strong ENSO events during the past 500 years and perhaps hundreds of events as strong as the 1982-1983 and 1997-1998 events during the Holocene (Colgan, 1990; Moy et al., 2002; Rein et al., 2005). Cores drilled from massive coral colonies (coral heads) throughout the Indo-Pacific display a trend toward more intense ENSO events after 1976 (Urban et al., 2000); however, although ENSO variability during the last century may be significantly higher than many times in the past, there is precedent in the fossil record for the intensity of recent events (Cobb et al., 2013). Whereas gross patterns of reef development have been examined in the eastern Pacific (Glynn and Macintyre, 1977; Macintyre et al., 1992; Cortés et al., 1994), biotic turnover, its climatic drivers, and its geological consequences remain understudied.

At least some effects of the 1982-1983 ENSO event were unprecedented on a scale of centuries. First, colonies of the massive corals Porites lobata and Pavona clavus in the Galápagos were 350-425 years old at the time of their death during the event (Glynn, 1990). Second, Dunbar et al. (1994) examined a colony of Pavona clavus that was part of the reef community at Urvina Bay in the Galápagos. In 1954, Urvina Bay was tectonically uplifted more than $7 \mathrm{~m}$, preserving in excellent detail the effects of a strong El Niño in 1941 (Colgan, 1990). The Pavona colony, which had survived the 1941 event, showed more than 350 years of continuous growth before its death in the 1954 uplift. Clearly, some massive corals had lived through previous, strong ENSO events. On 
the other hand, partial colony mortality and regeneration of the massive species $G$. planulata at Uva Island in the Gulf of Chiriquí marked both the 1982-1983 and 1997-1998 ENSOs, so even the latter event was not without ecological consequences (Wellington and Glynn, 2007).

More germane are Colgan's (1990) observations on uplifted stands of Pocillopora at Urvina Bay. Much of the Pocillopora was in poor taphonomic condition (but excellently preserved in that poor condition; Colgan and Malmquist, 1987), undoubtedly the result of 13 years of bioerosion by urchin grazing after the ENSO of 1941 and prior to the uplift. The uplifted reef contained clear evidence of bioerosive undercutting and collapse of the Pocillopora framework caused by sea urchins, Eucidaris galapagensis, quite similar to what was observed in living communities in the Galápagos after the 1982-1983 event. Furthermore, Eucidaris tests were scattered in large numbers at the base of the eroded Pocillopora framework.

The question of prior occurrence is important because, as discussed above, repeated El Niño events could explain why reefs are poorly developed in the eastern Pacific. Push cores that we extracted from uncemented reef frameworks in both the Gulf of Panama and the Gulf of Chiriquí appear to corroborate the pre-1982 ecological data, suggesting continuous dominance of Pocillopora for at least the last 1500 years (Toth et al., 2012, 2017). The ecological and paleobiological lines of evidence are not strictly comparable, however, because the temporal precision of cores may not be great enough to detect decadal-scale events. Can we identify mass coral kills and excursions from the Pocillopora-dominated state in the subfossil record of eastern Pacific reefs? The results of Colgan (1990) and post-1983 observations throughout the region imply that under the right conditions it should be possible to detect bioeroded horizons of Pocillopora and shifts in dominance between coral species.

Pocillopora-dominated reefs are not well developed in the eastern Pacific due to the narrow shelves on which they grow; exposure, in at least some locations, to cold and acidic upwelling waters; and episodic bleaching during ENSO events (Cortés et al., 1994; Glynn and Maté, 1997; Kleypas et al., 2006). Glynn and Colgan (1992) and Glynn (2000) argued that eastern Pacific reefs accrete poorly because the corals are periodically killed by severe El Niño events and then bioeroded by echinoids. Our study of the geologic record, in contrast, points to a protracted phase shift, during which the vertical accretion of Holocene reef frameworks off the Pacific coast of Panama was suppressed for far longer than the return time of strong ENSO events.

Our push cores from three fringing Panamanian reefs, which spanned a gradient of upwelling and water depths ( -0.8 to $-4.1 \mathrm{~m}$ relative to mean sea level), and which we dated with radiocarbon and uranium-series techniques, showed that vertical accretion essentially ceased from 4100 to $1600 \mathrm{BP}$ (Fig. 2; Toth et al., 2012). There is no evidence that the reefs shifted to lateral accretion at this time, as the reefs at all coring sites were growing over a paleodepth range of $\sim 1.6 \mathrm{~m}$ at the time they shut down (Lauren T. Toth, unpublished data). The hiatus in growth lasted approximately 2500 years, meaning the reefs were in a phase of negligible growth for as much as $40 \%$ of their history (Toth et al., 2012). Detailed core logs are provided in Toth, 2013).

Active coral growth was represented in the cores as long intervals of well preserved Pocillopora branch fragments. The hiatus manifested as a thin layer of taphonomically degraded Pocillopora branch fragments, coralline algae, and Psammocora stellata, all of which characterize ENSO-generated rubble fields on contemporary reefs in Pacific Panama. During the rest of their history, however, the reefs grew upward at rates comparable with the verticalaccretion rates of Caribbean reefs (Toth et al., 2012). The "poor" Holocene development of these reefs is, therefore, a consequence of the hiatus. The tempo and causality of reef development in Panama represent a vastly scaled-up version of the earlier model of Glynn and Colgan $(1992,2000)$, who had suggested that poor reef development was a consequence of decadal-scale disturbance by El Niño. Although ENSO suppresses populations of Pocillopora on subdecadal to multidecadal scales in Panama, slowed growth on those scales has not been the cause of low bulk-accretion rates through the Holocene.

\section{ENSO and coral reef collapse at $4.2 \mathrm{ka}$}

There is now broad consensus across both climate models and paleoclimate reconstructions that the middle Holocene was a period of relatively low ENSO variability (Sandweiss et al., 2001; Tudhope et al., 2001; Rein et al., 2005; Koutavas et al., 2006; Zheng et al., 2008; Cobb et al., 2013; Carré et al., 2014; Liu et al., 2014; Emile-Geay et al., 2016; Leonard et al., 2016b; Thompson et al., 2017). In particular, the interval 5-3 ka stands out as a period when paleoclimate records from throughout the tropical Pacific show a significant reduction in ENSO activity (Emile-Geay et al., 2016). Although the exact timing of the middle-Holocene ENSO minimum varies among reconstructions, some studies have suggested that there was exceptionally low ENSO variability between 4.3 and $4.2 \mathrm{ka}$ (Cobb et al., 2013; McGregor et al., 2013; Leonard et al., 2016b; Emile-Geay et al., 2016). Paradoxically, $\sim 4.2 \mathrm{ka}$ is also a point of inflection in most ENSO records, after which time ENSO variability increased, eventually leading to the establishment of the modern ENSO regime (Conroy et al., 2008; Koutavas and Joanides, 2012; Carré et al., 2014).

ENSO appears to be a primary control on modern coral growth and reef development in the TEP (Glynn and Colgan, 1992; Glynn et al., 2001; Toth et al., 2012, 2017). The dominant role of ENSO in modulating the ecology of contemporary reefs in the TEP led us to hypothesize that ENSO variability may also have shaped the dynamics of Panama- 


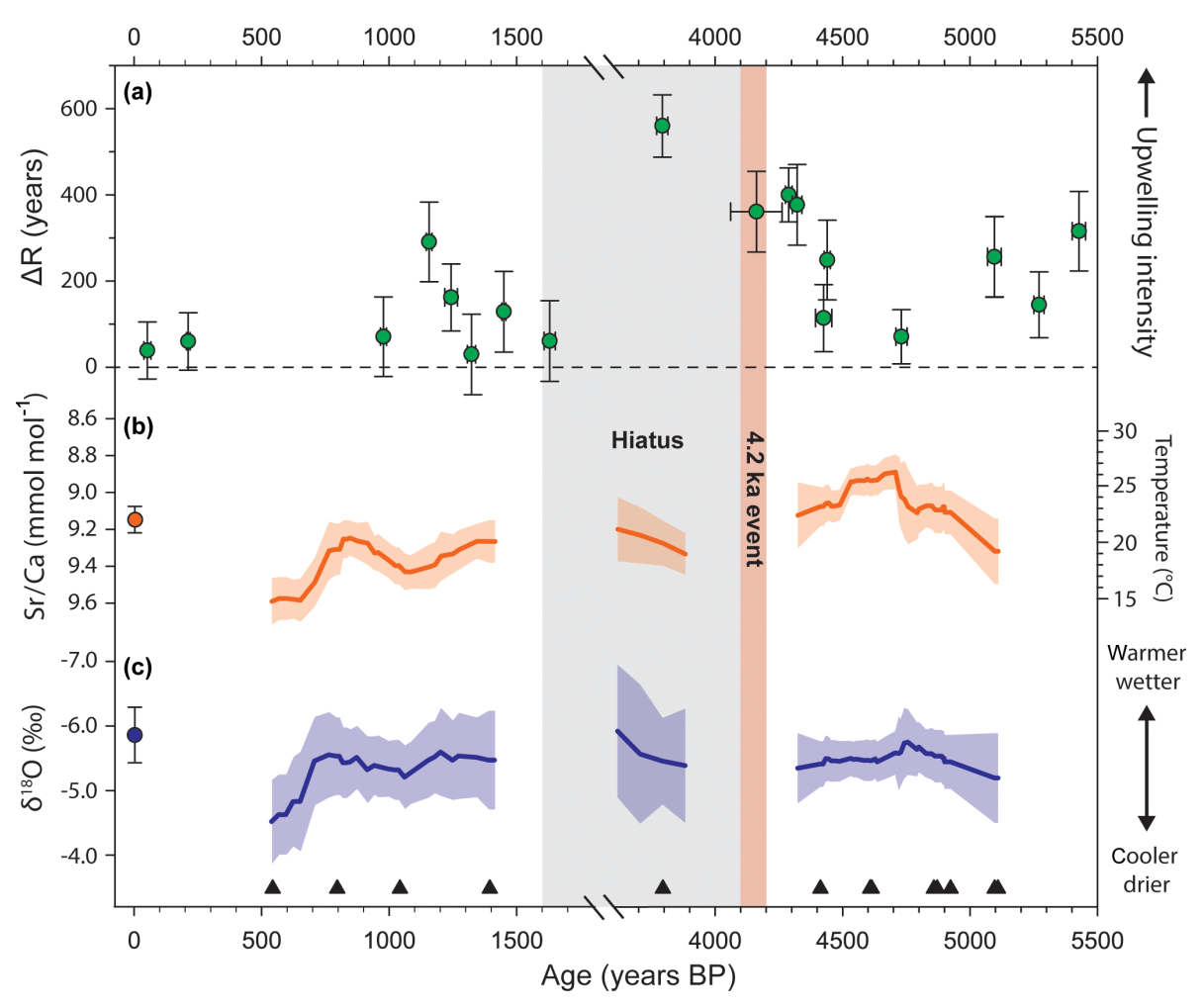

Figure 2. Coral-based reconstructions of oceanographic and climatic variability in Pacific Panama from 5500 BP to present (after Toth et al., 2015a, b). Plot (a) provides a reconstruction of upwelling intensity in the Gulf of Panama based on the location-specific radiocarbon-reservoir age offset, $\Delta R$ (Toth et al., 2015b). Plots (b) and (c) provide reconstructions of temperature and salinity variability for Pacific Panama based on 200-year running means ( $\pm 95 \%$ CIs, confidence intervals) of $\mathrm{Sr} / \mathrm{Ca}$ and $\delta^{18} \mathrm{O}$, respectively, of corals sampled from a core collected from the reef at Contadora Island in the Gulf of Panama. The individual data points used to generate the curves can be found in Toth (2013) and Toth et al. (2015a). Modern values are means ( $\pm 95 \%$ CIs) measured from living corals collected from the same reef in 2011 (described in Toth et al., 2015a). The timing of the $4.2 \mathrm{ka}$ event and the hiatus in the development of reefs in Pacific Panama are indicated by the red and gray bars, respectively.

nian reefs over millennial timescales. We tested the hypothesis that changes in ENSO activity around $4.2 \mathrm{ka}$ could have triggered reef shutdown in Pacific Panama by evaluating geochemical proxy records from corals in our cores in the Gulf of Panama (Fig. 2; Toth et al., 2015a, b). For obvious reasons, the availability of coral samples from the time of the hiatus was limited; however, we were able to analyze the $\mathrm{Sr} / \mathrm{Ca}$ and $\delta^{18} \mathrm{O}$ of seven coral skeletons that our age model suggested grew at the beginning of the hiatus $(\sim 3.9-$ $3.6 \mathrm{ka}$; Toth et al., 2015a). We also have a measurement of oceanic radiocarbon, a proxy for ocean circulation, from one coral that grew during this period (Toth et al., 2015b). Therefore, although we do not have any records at precisely $4.2 \mathrm{ka}$, our reconstructions give insights into the mean climatic and oceanographic states bounding $4.2 \mathrm{ka}$, which we evaluate in the context of records of ENSO variability from throughout the tropical Pacific presented in Fig. 3. Note that the schematic (Fig. 3) provides an overview of changes in ENSO, suggested by our work and the paleoclimate literature, that could have contributed to the shutdown of eastern
Pacific reef development. It is not meant as a comprehensive review of the literature.

Our record of oceanic radiocarbon variability suggests that upwelling was enhanced beginning at $4.3 \mathrm{ka}$ and continued to intensify over at least the next 500 years (Fig. 2a; Toth et al., 2015b). The hiatus in reef development was more protracted in the Gulf of Panama, implying that upwelling may have made reefs more sensitive to further environmental perturbations (Toth et al., 2012). Paleoclimate reconstructions, which we based on $\mathrm{Sr} / \mathrm{Ca}$ and $\delta^{18} \mathrm{O}$ in the coral skeletons, suggest that these oceanographic changes were followed by a transition to a cooler, wetter climate beginning by $\sim 3.9 \mathrm{ka}$ (Fig. 2b, c; Toth et al., 2015a). A lake record from the Galápagos recorded a contemporaneous period of anomalous drying, which in that location points to enhanced La Niña activity (Fig. 3; Conroy et al., 2008). Together, the inferred conditions indicate that an enhanced La Niña-like climate regime was established just after $4.2 \mathrm{ka}$, which could have provided the initial trigger that shut down reef development in Pacific Panama for the next 2500 years (Toth et al., 2012, 2015a). 


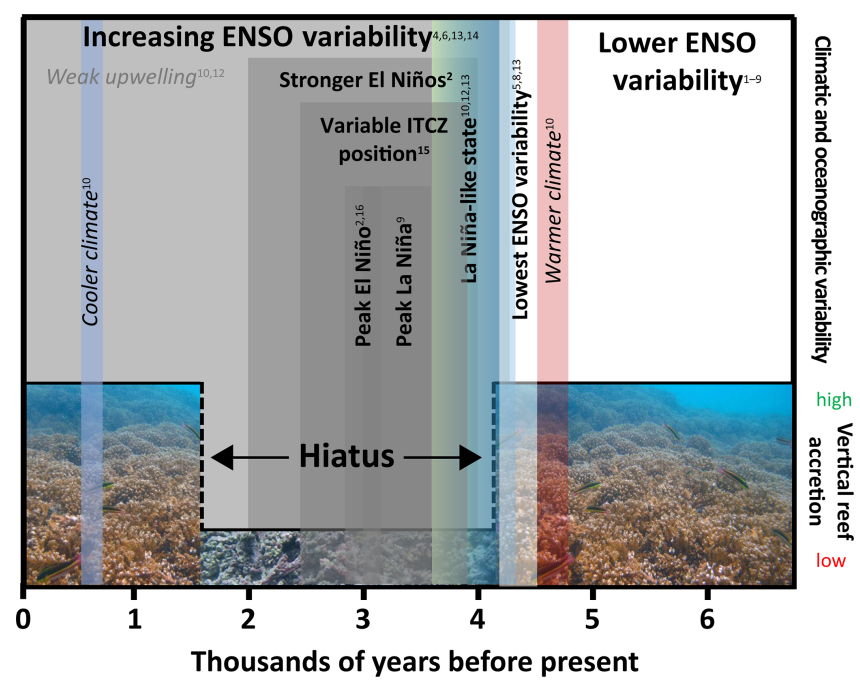

Figure 3. Schematic diagram of the reconstructed changes in ENSO variability in the tropical Pacific in relation to vertical reef accretion in Pacific Panama. Colored bars are based on a paleoceanographic reconstruction from Pacific Panama shown in Fig. 2; gray bars summarize the results of other paleoclimate studies from throughout the tropical Pacific. Superscripts reference the studies that support the climatic and oceanographic changes indicated in the bars: (1) Sandweiss et al. (2001); (2) Rein et al. (2005); (3) Zheng et al. (2008); (4) Koutavas and Joanides (2012); (5) Cobb et al. (2013); (6) Carré et al. (2014); (7) Emile-Geay et al. (2016); (8) Leonard et al. (2016b); (9) Thompson et al. (2017); (10) Toth et al. (2015a); (11) McGregor et al. (2013); (12) Toth et al. (2015b); (13) Conroy et al. (2008); (14) Corrège et al. (2000); (15) Haug et al. (2001); (16) Moy et al. (2002).

Whereas the period from 5 to 3 ka may have been a time of low ENSO variability on average (Emile-Geay et al., 2016), the time just after 4.2 ka was likely characterized by high climatic volatility in the tropical Pacific (Fig. 3). At least one record, from Vanuatu in the western Pacific, indicates that a multidecadal period of enhanced ENSO variability followed just 500 years after the putative low in ENSO activity at $\sim 4.2 \mathrm{ka}$ (Corrège et al., 2000); however, we note that there is less evidence for elevated ENSO variability in a contemporaneous record from nearby New Caledonia (Emile-Geay et al., 2016). Our data from Pacific Panama suggest that the period after $4.2 \mathrm{ka}$ would have been followed by a transition to La Niña-like conditions by $3.9 \mathrm{ka}$ (Toth et al., 2015a, b), and another recent study suggests that La Niña events were also more frequent from 3.5-3 ka (Thompson et al., 2017). A record of El Niño-related flooding from Peru implies that the strongest El Niño events of the Holocene occurred 4$2 \mathrm{ka}$ (Rein et al., 2005), and a series of records from the same region suggest a possible peak in the frequency of El Niño events around $3 \mathrm{ka}$ (Sandweiss et al., 2001; Moy et al., 2002). We note, however, that recent reanalysis has called the latter conclusion into question (Emile-Geay and Tingley, 2016). The beginning of the late Holocene was also characterized by a period of high variability in the position of the Intertropical Convergence Zone (ITCZ), supporting the idea that regional climatic variability was high at the time (Haug et al., 2001). Taken together, these studies support the conclusion that ENSO variability was enhanced after $4.2 \mathrm{ka}$ (Conroy et al., 2008; Koutavas and Joanides, 2012; Carré et al., 2014).

Stronger and/or more frequent El Niño and La Niña events would have acted to suppress reef development after $4.2 \mathrm{ka}$ (Toth et al., 2012). ENSO variability continued to increase after the end of the hiatus in reef development (Conroy et al., 2008; Cobb et al., 2013; Thompson et al., 2017); however, major changes in the mode of ENSO coincided with its termination (Fig. 3). First, the variability in the mean position of the ITCZ had declined by $\sim 2.5 \mathrm{ka}$ (Haug et al., 2001). Second, although ENSO variability and the absolute number of El Niño events may have increased beginning $2 \mathrm{ka}$ (Sandweiss et al., 2001; McGregor and Gagan, 2004; Conroy et al., 2008; Thompson et al., 2017), El Niño events were likely stronger (Rein et al., 2005) and La Niña events may have been more frequent (Thompson et al., 2017) during the hiatus. Our records suggest that upwelling was more moderate after the hiatus (Fig. 2a), which would indicate that there were fewer or less extreme La Niña events. Furthermore, because the climate remained relatively cool after the hiatus (Fig. 2b), it is likely that the influence of El Niño events had also decreased. We hypothesize that the waning influence of La Niña and reduction in El Niño strength permitted accretion to resume between $\sim 1.8$ and $1.5 \mathrm{ka}$ (Toth et al., 2012, 2015a).

We conclude that ENSO was likely the primary driver of the collapse of coral reefs in Pacific Panama and, perhaps, other locations around the tropical Pacific at $\sim 4.2 \mathrm{ka}$. The fact that the shutdown in reef accretion occurred in both the Gulf of Panama and the Gulf of Chiriquí excludes upwelling and outbreaks of Acanthaster as drivers: upwelling is weak or absent in the Gulf of Chiriquí, and Acanthaster is absent from the Gulf of Panama. Other possible factors, including changes in relative sea level, tectonics, and bioerosion, cannot explain the observed patterns either (Toth et al., 2012, 2015a). The potential role of changing ENSO variability in ecological changes elsewhere at this time is less clear, but there is some evidence to support the idea: increased ENSOlike variability in the climate of eastern China is temporally correlated with an inferred increase in coral bleaching around $4.2 \mathrm{ka}$ (Li et al., 2018; Xu et al., 2018). Furthermore, even if enhanced ENSO variability triggered reef shutdown in the TEP at $4.2 \mathrm{ka}$, that does not mean ENSO-related changes necessarily accounted for the next 2500 years of suppressed reef development; Fig. 3 implies a concatenation of conditions that might or might not have been dependent or semiindependent. Some evidence does in fact point to climatic shifts around the time of the $4.2 \mathrm{ka}$ event that persisted for millennia (Selvaraj et al., 2008).

There is still considerable disagreement about timing and magnitude of the putative shifts in ENSO variability during 
the middle to late Holocene (Emile-Geay et al., 2016). One problem in linking ENSO as a driver or response to the $4.2 \mathrm{ka}$ event is the asymmetry in the ENSO signal between the eastern and central Pacific that can be observed from both recent El Niño events (Fig. 4; Takahashi et al., 2011) and the Holocene record (Carré et al., 2014; Karamperidou et al., 2015). Indeed, there appear to be two distinct "flavors" of ENSO based on the location of the strongest thermal anomalies - eastern Pacific and central Pacific events - and the dominance of these ENSO modes may have varied over millennial timescales (Karamperidou et al., 2015). Another problem is the large temporal uncertainties associated with many of the existing paleoclimate records of ENSO. Currently, it is not possible to clearly resolve the centennial-scale shifts in ENSO variability around $4.2 \mathrm{ka}$. Reducing the temporal uncertainties in paleo-ENSO records at $4.2 \mathrm{ka}$ and the dominant flavor of ENSO at this time, by targeting ENSO proxies from throughout the tropical Pacific, will be a critical step to determining whether shifts in ENSO variability can be linked to the $4.2 \mathrm{ka}$ event on a geographic scale and the subsequent 2.5 millennia of impacts on reefs throughout the tropical Pacific.

\section{Regional- to global-scale impacts of ENSO and the 4.2 ka event}

ENSO is the most prominent interannual driver of globalscale climate variability. Although it originates in the tropical Pacific, it impacts regional climates around the world (McPhaden et al., 2006). The global impacts of ENSO are primarily a result of the influence of ENSO-based sea-surface temperature anomalies on other drivers of climate variability such as the ITCZ, the Asian monsoon, and the North Atlantic Oscillation (NAO). For example, the warm (cool) tropical Pacific sea-surface temperatures associated with El Niño (La Niña) generally drive a southerly (northerly) shift in the mean position of the ITCZ, which results in changes in precipitation from the tropical Pacific to the neotropics, to Africa (Haug et al., 2001; Chaing et al., 2002; Sachs et al., 2009). Similarly, the Asian monsoon is generally suppressed during El Niño events and enhanced during La Niña events (Liu et al., 2000; Wang et al., 2003). Although the relationship between ENSO and the NAO, which has a strong influence on European climates, is less straightforward, the NAO is typically negative (positive) during El Niño (La Niña) events (Rodríguez-Foncesca et al., 2016).

The global impacts of El Niño and La Niña events can significantly vary from event to event; however, there are striking spatial correlations between the global signature of ENSO (summarized in Davey et al., 2013) and that of the $4.2 \mathrm{ka}$ event. In the majority of the records to date, the $4.2 \mathrm{ka}$ event has been characterized by changes in terrestrial hydroclimate (Weiss, 2016). Whereas the event was characterized by widespread aridification in southern Europe, the Mid- dle East, northern Africa, midcontinental North America, and parts of eastern and southwest Asia (Weiss et al., 1993; Staubwasser et al., 2003; Marchant and Hooghiemstra, 2004; Booth et al., 2005; Xiao et al., 2018), other locations, such as western South America, experienced marked increases in precipitation (Marchant and Hooghiemstra, 2004). With the exception of Europe, which is weakly teleconnected with ENSO, the mean shifts in precipitation that occurred during the $4.2 \mathrm{ka}$ event are generally consistent with those observed during a typical El Niño event (Davey et al., 2013). The changes in hydroclimate during typical El Niño events even replicate the zonal gradient in precipitation observed across northern South America at $\sim 4.2 \mathrm{ka}$ (Marchant and Hooghiemstra, 2004; McPhaden et al., 2006; Davey et al., 2013).

Like many records of ENSO variability from the tropical Pacific, our records from Pacific Panama do not display a sudden change in El Niño activity at $4.2 \mathrm{ka}$ (Toth et al., 2015a; Emile-Geay et al., 2016); however, most reconstructions of Holocene ENSO suggest that there was a transition to increasing ENSO variability around this time (Conroy et al., 2008; Koutavas and Joanides, 2012; Cobb et al., 2013; Carré et al., 2014). Whereas the $4.2 \mathrm{ka}$ event manifested as an abrupt short-lived climatic event in many locations, the larger-scale climatic and ecosystem responses to the event may have been more protracted. Increased ENSO variability could in this sense be a response to the abrupt climate changes associated with the $4.2 \mathrm{ka}$ event. In Pacific Panama, the onset of reef collapse just after $4.2 \mathrm{ka}$ was associated with a transition to a cooler, La Niña-like climate (Toth et al., 2015; see also Cabarcos et al., 2014), which triggered a regime shift that lasted for millennia. Similarly, there is evidence that the onset of aridification in the mid-continental United States was followed by glacial advances in western Canada, from 4.2 to $3.8 \mathrm{ka}$, associated with a cooler, wetter climate (Menounos et al., 2008; Mayewksi et al., 2004) that is characteristic of La Niña conditions in that region (Davey et al., 2013). Whereas a number of records indicate a weaker East Asian monsoon around $4.2 \mathrm{ka}$, indicative of an El Niño-like climate (Staubwasser et al., 2003), there is also evidence that some regions of southern Asia became wetter, or more La Niña-like, after $4.2 \mathrm{ka}$ (reviewed in $\mathrm{Wu}$ and Liu, 2004). Thus, although many of the abrupt changes in terrestrial hydroclimate during the $4.2 \mathrm{ka}$ event resemble those observed during El Niño events, the ecosystem changes following the $4.2 \mathrm{ka}$ event could also reflect responses to secondary changes in regional climatic systems.

We are not arguing that ENSO was necessarily an ultimate cause of the $4.2 \mathrm{ka}$ event; however, the shift in ENSO variability after $4.2 \mathrm{ka}$ and the similarity between the global impacts of ENSO and the global footprint of the $4.2 \mathrm{ka}$ event suggest a potential connection. The climatic forcing that produced the changes in ENSO variability during the middle Holocene are still being debated, but it is generally thought that changes in ENSO during the Holocene have 

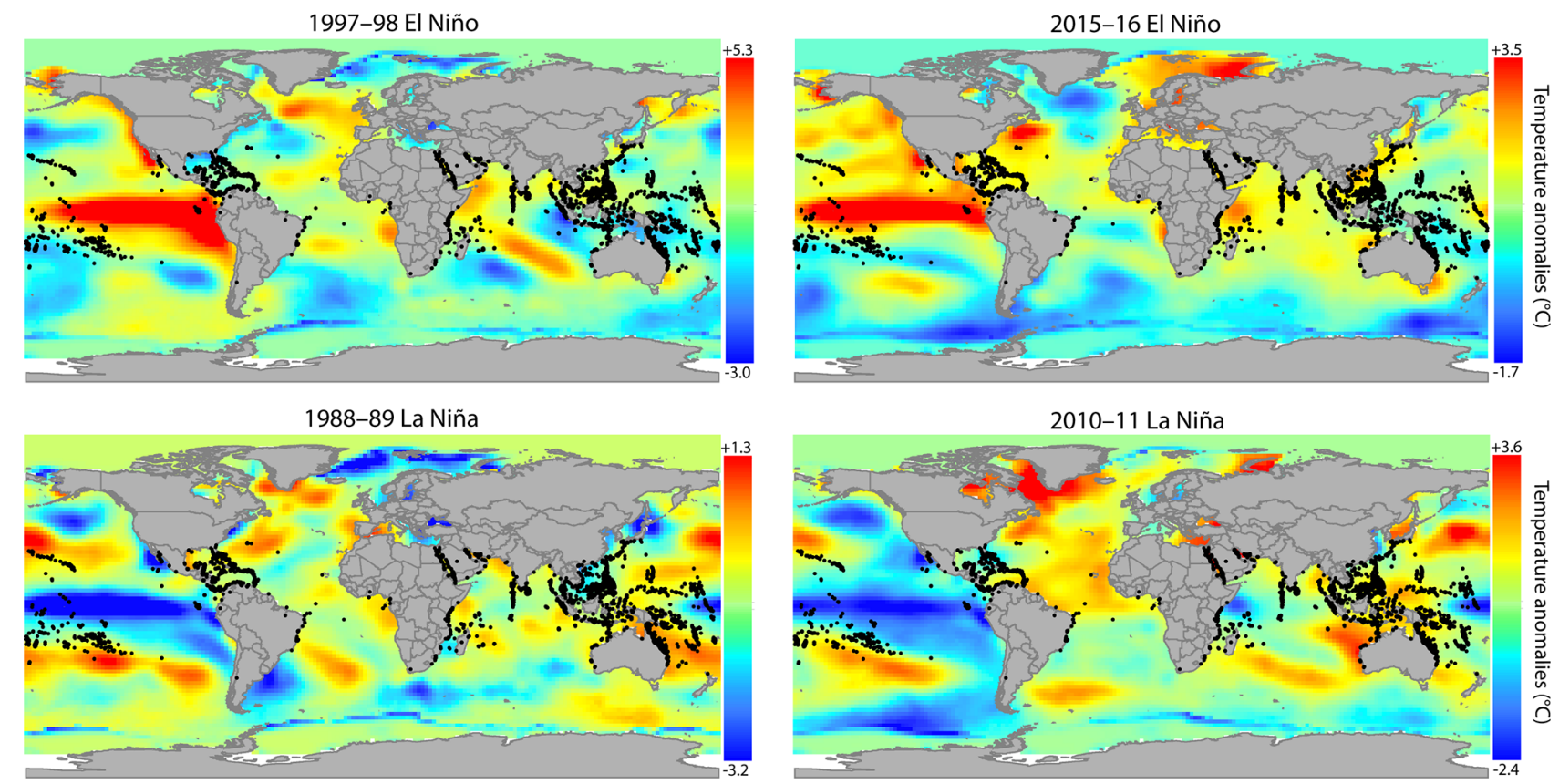

Figure 4. Thermal anomalies associated with two of the strongest El Niño events (1997-1998 and 2015-2016) and La Niña events (19881989 and 2010-2011) in recent history. Black points on the maps indicate the locations of coral reefs. The imagery was created with data from NOAA's Smith and Reynolds Extended Reconstructed Sea Surface Temperature, Level 4 monthly dataset (V5) using NASA's PO.DAAC LAS V8.6.1 visualization tool (https://podaac-tools.jpl.nasa.gov/las/, last access: 1 July 2019).

Table 1. Summary of records of perturbations to coral reef ecosystems around the time of the 4.2 ka event. Reported radiocarbon ages were calibrated with the marine radiocarbon curve and regional marine reservoir age corrections, using CALIB software (v.7.0.2; Stuiver et al., 2018).

\begin{tabular}{llll}
\hline Type of impact & Location & Time period (kyr BP) & Reference \\
\hline $\begin{array}{l}\text { Hiatus in reef } \\
\text { development }\end{array}$ & Pacific Panama & & \\
& Contadora & $4.3-1.5$ & Toth et al. (2012) \\
& Iguana & $4.2-1.6$ & Toth et al. (2012) \\
& Canales de Tierra & $4.0-1.8$ & Toth al. (2012) \\
& Costa Rica & Cortés et al. (1994) \\
& Golfo Dulce & $4.6-2.0$ & Lybolt et al. (2011) \\
& Great Barrier Reef & & Hamanaka et al. (2012) \\
& Moreton Bay & $4.2-2.0$ & \\
& Japan & & Rooney et al. (2004) \\
& Kodakara Island & $4.4-4.0$ & Rooney et al. (2004) \\
& Hawaii & & Rooney et al. (2004) \\
& Kailua, O'ahu & $5.0-$ present & Rooney et al. (2004) \\
\hline Shutdown of reef development & Punalu'u, O'ahu & $4.9-$ present & \\
& Hale o Lono, Moloka'i & $4.8-$ present & Xu et al. (2018) \\
\hline Coral mortality & Mana, Kaua'i & $4.5-0$ & Toth et al. (2015) \\
& China & & Xu et al. (2018) \\
\hline Decline in coral $\delta^{13} \mathrm{C}$ & South China Sea & $4.2-3.8$ &
\end{tabular}


been driven by gradual changes in the climate system associated with changing insolation and/or feedbacks with annual climate cycles (McPhaden et al., 2006; McGregor et al., 2013; Emile-Geay et al., 2016;). For example, several researchers (Koutavas et al., 2006; McGregor et al., 2013) have suggested that the weaker ENSO variability observed in the central Pacific at $\sim 4.3 \mathrm{ka}$ was related to the more northerly ITCZ at this time, which would have also enhanced eastern Pacific upwelling, produced cooler sea temperatures in the TEP, and driven a stronger zonal gradient in sea-surface temperature that suppressed ENSO (Clement et al., 2000). In the absence of a clear high-latitude driver for the $4.2 \mathrm{ka}$ event, these changes in the tropical ocean must be considered as potential contributors to the $4.2 \mathrm{ka}$ event (Marchant and Hooghiemstra, 2004).

\section{Prospectus}

Because the global teleconnections of El Niño and La Niña can significantly vary from event to event (Fig. 4; McPhaden et al., 2006), ecosystems of the tropical and subtropical Pacific are likely to yield the best evidence for evaluating the potential role of ENSO in the $4.2 \mathrm{ka}$ event. Corals and coral reef communities that were living under chronically stressed conditions should have been particularly vulnerable to increased ENSO variability after $4.2 \mathrm{ka}$. If the hiatus was triggered by La Niña-like conditions (Fig. 4), the $4.2 \mathrm{ka}$ event should be most strongly manifested in reef records from areas of upwelling and in seasonally cooler subtropical environments (compared with less-seasonal tropical environments). Nearshore habitats, which are more influenced by the thermal swings and high sedimentation rates associated with terrigenous input, should be more vulnerable compared with reefs exposed to clearer oceanic waters. Reefs off the Pacific coast of Panama and Costa Rica, which are exposed to a strong terrigenous influence and (in some areas) strong upwelling, display the hiatus (Table 1; Cortés et al., 1994; Toth et al., 2012). Latitudinally marginal lagoonal habitats elsewhere in the Pacific should also manifest the hiatus (see Cruz et al., 2018). Preliminary evidence corroborates that hypothesis in the western Pacific in turbid lagoonal habitats south of the Great Barrier Reef, in southern China, and in Japan (Table 1; Lybolt et al., 2011; Hamanaka et al., 2012; Yamano et al., 2012; Xu et al., 2018); however, falls or stillstands in relative sea level in the western Pacific after the middle Holocene likely also contributed to stalled vertical reef growth during the late Holocene in many locations (e.g., Dechnik et al., 2018), making it more difficult to discern the impacts of climatic variability and also potentially introducing variability into the start times of hiatuses in reef accretion. Other possible causes of variations in the start times listed in Table 1 include the artifactual absence of coral material of particular ages in particular samples and the uncertainty associated with the dating techniques. Whether La Niña-driven reef shutdown occurred broadly on subtropical reefs of the central Pacific remains a topic of active research, but there is some evidence that increased wave energy tied to ENSO suppressed vertical reef accretion in Hawaii around the time of the $4.2 \mathrm{ka}$ event (Table 1; Grossman and Fletcher, 2004; Rooney et al., 2004).

By contrast, the impacts of increased El Niño intensity that followed the putative increase in La Niña activity (Figs. 3, 4) might have been attenuated in lagoonal and nearshore habitats, where turbidity associated with terrigenous runoff from increased precipitation (in many locations, though not in Panama) would have decreased light penetration and thereby offered a measure of protection from bleaching (Perry et al., 2012; Cacciapaglia and van Woesik, 2015). Above some threshold amplitude, however, the ENSO swings would have overwhelmed the capacity of even turbid-water reefs to resist bleaching (e.g., Aronson et al., 2002). Furthermore, El Niño conditions are accompanied by increased precipitation in most places, with potentially negative impacts on corals.

Across the equatorial Pacific, contemporary corals and coral reefs at longitudes that have experienced higher temperatures over the previous century have proven more resistant to bleaching events. The eastern and central Pacific, including tropical as well as subtropical areas, have thus been more vulnerable for historical reasons than the western Pacific (Thompson and van Woesik, 2009). If the short-term geographic patterns of ENSO history are indicative of patterns earlier in the Holocene, then on the basis of El Niñotype impacts we would expect the $4.2 \mathrm{ka}$ event to have manifested strongly in the eastern and central Pacific, and less so in the western Pacific. This hypothesis could be tested by coring Holocene reef frameworks across the Pacific near the Equator. The physiographic marginality of individual reefs, resulting from additional sources of environmental variability (such as upwelling) and their particular ecologies (including their species diversity), would have decreased their resilience and thereby increased the likelihood that El Niño disturbances would have left a signature in their fossil record.

Cobb et al. (2013) documented low ENSO variability at $4.2 \mathrm{ka}$ at Kiritimati in the Line Islands of the central Pacific. That result potentially falsifies our hypothesis of an event at $4.2 \mathrm{ka}$ being strongly manifested in reef frameworks of the central Pacific, as well as the idea that contemporary geographic patterns of ENSO variability reflect patterns that prevailed $4.2 \mathrm{ka}$. There is some evidence that the eastern Pacific mode of ENSO was dominant after $\sim 4.5 \mathrm{ka}$ (Carré et al., 2014), which may explain the muted response to the $4.2 \mathrm{ka}$ event in the central Pacific. Parsing the spatially variable impacts of ENSO and other drivers, such as relative sea level, upwelling, climatic effects other than ENSO, and local physiography and hydrography, to explain patterns of reef development will be a significant challenge going forward (for the Great Barrier Reef: Dechnik et al., 2015; Leonard et al., 2016a, b; Ryan et al., 2018; Webster et al., 2018; see Toth et al., 2016, for the eastern Pacific). 
The preponderance of research to date on the causes and consequences of the $4.2 \mathrm{ka}$ event has focused on terrestrial environments and cultural impacts. In this paper we have shown that there were significant perturbations to coral reef environments in Pacific Panama and throughout the tropical Pacific around $4.2 \mathrm{ka}$. Without a clear high-latitude driver for the $4.2 \mathrm{ka}$ event, it stands to reason that the climatic changes around this time could have originated in the tropical oceans and may have been related to contemporaneous changes in ENSO variability. Coral reef archives could provide the key to discerning the role of ENSO in the $4.2 \mathrm{ka}$ event.

A strong role for ENSO in the 4.2 ka event would have important implications for living coral populations and future reef accretion in the TEP. Contemporary climate change will likely increase ENSO variability in the eastern Pacific (Cai et al., 2018). A robust connection between ENSO variability and reef development could, therefore, portend another shutdown of eastern Pacific reefs.

Data availability. Some of the data reviewed in this paper are available through references cited in the figure captions.

Author contributions. LTT and RBA contributed equally to the conception and writing of this manuscript.

Competing interests. The authors declare that they have no conflict of interest.

Special issue statement. This article is part of the special issue "The $4.2 \mathrm{ka} \mathrm{BP}$ climatic event". It is a result of "The $4.2 \mathrm{ka} \mathrm{BP}$ Event: An International Workshop", Pisa, Italy, 10-12 January 2018.

Acknowledgements. This paper grew out of an international workshop, "The $4.2 \mathrm{kaBP}$ Event", which was organized by Giovanni Zanchetta, Harvey Weiss, and Monica Bini and held in the Dipartimento di Scienzi della Terra at the University of Pisa in January 2018. We thank the organizers for the opportunity to participate in the workshop. Raymond Bradley, Mark Bush, Evan Edinger, Nicholas Graham, William Precht, Julie Richey, Robert van Woesik, Harvey Weiss, and two anonymous reviewers provided valuable advice and discussion. Our research was supported by grant OCE-1535007 from the US National Science Foundation. Toth's research is also funded by the Coastal and Marine Hazards and Resources Program of the United States Geological Survey. This is contribution number 203 from the Institute for Global Ecology at the Florida Institute of Technology. Any use of trade, firm, or product names is for descriptive purposes only and does not imply endorsement by the US Government.

Edited by: Harvey Weiss

Reviewed by: Evan Edinger and two anonymous referees

\section{References}

Anthony, K. R. N.: Coral reefs under climate change and ocean acidification: challenges and opportunities for management and policy, Annu. Rev. Env. Resour., 41, 59-81, 2016.

Aronson, R. B. and Precht, W. F.: Evolutionary paleoecology of Caribbean coral reefs, in: Evolutionary paleoecology: the ecological context of macroevolutionary change, edited by: Allmon, W. D. and Bottjer, D. J., Columbia University Press, New York, 171-233, 2001.

Aronson, R. B., Precht, W. F., Toscano, M. A., and Koltes, K. H.: The 1998 bleaching even and its aftermath on a coral reef in Belize, Mar. Biol., 141, 435-447, 2002.

Baker, A. C., Starger, C. J., McClanahan, T. R., and Glynn, P. W.: Corals' adaptive response to climate change, Nature, 430, p. 741, 2004.

Booth, R. K., Jackson, S. T., Forman, S. L., Kutzbach, J. E., Bettis III, E. A., Kreigs, J., and Wright, D. K.: A severe centennialscale drought in midcontinental North America 4200 years ago and apparent global linkages, Holocene, 15, 321-328, 2005.

Brown, B. E.: Worldwide death of corals: natural cyclical events or man-made pollution, Mar. Poll. Bull., 18, 9-13, 1987.

Buddemeier, R. W., Kleypas, J. A., and Aronson, R. B.: Coral reefs and global climate change: potential contributions of climate change to stresses on coral reef ecosystems, Pew Center on Global Climate Change, Arlington, Virginia, USA, 2004.

Cabarcos, E., Flores, J.-A., and Sierro, F. J.: High-resolution productivity record and reconstruction of ENSO dynamics during the Holocene in the Eastern Equatorial Pacific using coccolithophores, Holocene, 24, 176-187, 2014.

Cacciapaglia, C. and van Woesik, R.: Reef-coral refugia in a rapidly changing ocean, Glob. Change Biol., 21, 2272-2282, 2015.

Cai, W., Wang, J., Dewitte, B., Wu, L., Santoso, A., Takahashi, K., Yang, Y., Carréric, A., and McPhaden, M. J.: Increased variability of eastern Pacific El Niño under greenhouse warming, Nature, 564, 201-206, 2018.

Carré, M., Sachs, J. P., Purca, S. Schauer, A., Braconnot, P., Falcón, R. A., Julien, M., and Lavallée, D.: Holocene history of ENSO variance and asymmetry in the eastern tropical Pacific, Science, 345, 1045-1048, 2014.

Chaing, J. C. H., Kushnir, Y., and Giannini, A.: Deconstructing Atlantic Intertropical Convergence Zone variability: influence of the local cross-equatorial sea surface temperature gradient and remote forcing from the eastern equatorial Pacific, J. Geophys. Res., 107, JD000307, https://doi.org/10.1029/2000JD000307, 2002.

Clement, A., Seager, R., Cane, M. A., and Zebiak, S. E.: An ocean dynamical thermostat, J. Clim., 9, 2910-2196, 2000.

Cobb, K. M., Westphal, N., Sayani, H. R., Watson, J. T., Di Lorenzo, E., Cheng, H., Edwards, R. L., and Charles, C. D.: Highly variable El Niño-Southern Oscillation throughout the Holocene, Science, 339, 67-70, 2013.

Colgan, M. W.: El Niño and the history of eastern Pacific reef building, in: Global ecological consequences of the 1982-83 El NiñoSouthern Oscillation, edited by: Glynn, P. W., Elsevier, Amsterdam, 183-232, 1990.

Colgan, M. W. and Malmquist, D. L.: The Urvina Bay uplift: a dry trek through a Galápagos coral reef, Oceanus, 30, 61-66, 1987. 
Combosch, D. J. and Vollmer, S. V.: Population genetics of an ecosystem-defining reef coral Pocillopora damicornis in the tropical eastern Pacific, PloS ONE, 6, e21200, https://doi.org/10.1371/journal.pone.0021200, 2011.

Combosch, D. J., Guzmán, H. M, Schuhmacher, H., and Vollmer, S. V.: Interspecific hybridization and restricted trans-Pacific flow in the tropical eastern Pacific Pocillopora, Mol. Ecol., 17, 13041312, 2008.

Conroy, J. L., Overpeck, J. T., Cole, J. E., Shanahan, T. M., and Steinitz-Kannan, M.: Holocene changes in eastern tropical Pacific climate inferred from a Galápagos lake sediment record, Quaternary Sci. Rev., 27, 1166-1180, 2008.

Cortés, J.: Comparison between Caribbean and eastern Pacific coral reefs, Rev. Biol. Trop., 41, 19-21, 1993.

Cortés, J.: Biology and geology of eastern Pacific coral reefs, Coral Reefs, 16, S39-S46, 1997.

Cortés, J., Macintyre, I. G., and Glynn, P. W.: Holocene growth history of an eastern Pacific fringing reef, Punta Islotes, Costa Rica, Coral Reefs, 13, 65-73, 1994.

Corrège, T., Delcroix, T., Réey, J., Beck, W., Cabioch, G., and Le Cornec, F.: Evidence for stronger El Niño-Southern Oscillation (ENSO) events in a mid-Holocene massive coral, Paleoceanography, 15, 465-470, 2000.

Cruz, I. G. S., Waters, L. G., Kikuchi, R. K. P., Leão, Z. M. A. N., and Turra, A.: Marginal coral reefs show high susceptibility to phase shift, Mar. Pollut. Bull., 135, 551-561, 2018.

Dansgaard, W., Johnsen, S. J., Clausen, H. B., Dahl-Jensen, D., Gundestrup, N. S., Hammer, C. U., Hvidberg, C. S., Steffensen, J. P., Sveinbjörnsdottir, A. E., Jouzel, J., and Bond, G.: Evidence for general instability of past climate from a 250-kyr ice-core record, Nature, 364, 218-220, 1993.

Darwin, C.: The structure and distribution of coral reefs (reprinted), University of California Press, Berkeley, California, 214 pp., 1862.

Davey, M. K., Brookshaw, A., and Ineson, S.: The probability of the impact of ENSO on precipitation and near-surface temperature, Clim. Risk Manage., 1, 5-24, 2014.

D’Croz, L. and Maté, J. L.: Experimental responses to elevated water temperature in genotypes of the reef coral Pocillopora damicornis from upwelling and non-upwelling environments in Panama, Coral Reefs, 23, 473-483, 2004.

Dechnik, B., Webster, J. M., Davies, P. J., Braga, J.-C., and Reimer, P. J.: Holocene "turn-on" and ecolution of the southern Great Barrier Reef: revisiting reef cores from the Capricorn Bunker Group, Mar. Geol., 363, 174-190, 2015.

Donner, S. D., Skirving, W. J., Little, C. M., Oppenheimer, M., and Hoegh-Guldberg, O.: Global assessment of coral bleaching and required rates of adaptation under climate change, Glob. Change Biol., 11, 2251-2265, 2005.

Dunbar, R. B., Wellington, G. M., Colgan, M. W., and Glynn, P. W.: Eastern Pacific sea surface temperature since 1600 A.D.: the ${ }^{18} \mathrm{O}$ record of climate variability in Galápagos corals, Paleoceanography, 9, 291-315, 1994.

Eakin, C. M.: Where have all the carbonates gone? A model comparison of calcium carbonate budgets before and after the 19821983 El Niño at Uva Island in the eastern Pacific, Coral Reefs, 15, 109-119, 1996.
Eakin, C. M.: A tale of two ENSO events: carbonate budgets and the influence of two warming disturbances and intervening variability, Uva Island, Panama, Bull. Mar. Sci., 69, 171-186, 2001.

Eakin, C. M. and Glynn, P. W.: Low tidal exposures and reef mortalities in the eastern Pacific, Coral Reefs, 15, p. 120, 1996.

Emile-Geay, J. and Tingley, M.: Inferring climate variability from nonlinear proxies: application to palaeo-ENSO studies, Clim. Past, 12, 31-50, https://doi.org/10.5194/cp-12-31-2016, 2016.

Emile-Geay, J., Cobb, K. M., Carré, M., Braconnot, P., Leloup, J., Zhou, Y., Harrison, S. P., Corrège, T., McGregor, H. V., Collins, M., Driscoll, R., Elliot, M., Schneider, B., and Tudhope, A.: Links between tropical Pacific seasonal, interannual and orbital variability during the Holocene, Nat. Geosci., 9, 168-175, 2016.

Enfield, D. B.: Evolution and historical perspective of the 19971998 El Niño-Southern Oscillation event, Bull. Mar. Sci., 69, 7-25, 2001.

Flannery, J. A., Richey, J. N., Toth, L. T., Kuffner, I. B., and Poore, R. Z.: 2018. Quantifying uncertainty in coral Sr/Cabased SST estimates from Orbicella faveolata: A basis for multicolony SST reconstructions, Paleoceanogr. Paleocl., 33, 958973, https://doi.org/10.1029/2018PA003389.

Fong, P. and Glynn, P. W.: Population abundance and size-structure of an eastern tropical Pacific reef coral after the 1997-98 ENSO: a simulation model predicts field measures, Bull. Mar. Sci., 69, 187-202, 2001.

Ginsburg, R. N. and Shinn, E. A.: Preferential distribution of reefs in the Florida reef tract: the past is the key to the present, in: Proceedings of the Colloquium on Global Aspects of Coral Reefs: Health, Hazards, and History, edited by: Ginsburg, R. N., Rosenstiel School of Marine and Atmospheric Science, University of Miami, Coral Gables, Florida, 21-26, 1994.

Glynn, P. W.: Some physical and biological determinants of coral community structure in the eastern Pacific, Ecol. Monogr., 46, 431-456, 1976.

Glynn, P. W.: El Niño-associated disturbance to coral reefs and postdisturbance mortality by Acanthaster planci, Mar. Ecol. Prog. Ser., 26, 295-300, 1985.

Glynn, P. W.: El Niño-Southern Oscillation 1982-1983: nearshore population, community, and ecosystem responses, Annu. Rev. Ecol. Syst., 19, 309-345, 1988a.

Glynn, P. W.: El Niño warming, coral mortality and reef framework destruction by echinoid bioerosion in the eastern Pacific, Galaxea, 7, 129-160, 1988b.

Glynn, P. W.: Coral mortality and disturbances to coral reefs in the tropical eastern Pacific, in: Global ecological consequences of the 1982-83 El Niño-Southern Oscillation, edited by: Glynn, P. W., Elsevier, Amsterdam, 55-125, 1990.

Glynn, P. W.: Coral reef bleaching in the 1980s and possible connections with global warming, Trend. Ecol. Evol., 6, 175-179, 1991.

Glynn, P. W.: El Niño-Southern Oscillation mass mortalities of reef corals: a model of high temperature marine extinctions?, in: Carbonate platform systems: components and interactions, edited by: Insalaco, E., Skelton, P. W., and Palmer, T. J., Geological Society of London Special Publication 178, London, 117-133, 2000.

Glynn, P. W.: High complexity food webs in low-diversity eastern Pacific reef-coral communities, Ecosystems, 7, 358-367, 2004. 
Glynn, P. W. and Ault, J. S.: A biogeographic analysis and review of the far eastern Pacific coral reef region, Coral Reefs, 19, 1-23, 2000.

Glynn, P. W. and Colgan, M. W.: Sporadic disturbances in fluctuating coral reef environments: El Niño and coral reef development in the eastern Pacific, Am. Zool., 32, 707-718, 1992.

Glynn, P. W. and Macintyre, I. G.: Growth rate and age of coral reefs on the Pacific coast of Panama, Proc. 3rd Int. Coral Reef Symp., Miami, 2, 251-259, 1977.

Glynn, P. W. and Maté, J. L.: Field guide to the Pacific coral reefs of Panamá, Proc. 8th Int. Coral Reef Symp., Panama, 1, 145-166, 1997.

Glynn, P. W., Maté, J. L., Baker, A. C., and Calderón, M.: Coral bleaching and mortality in Panama and Ecuador during the 19971998 El Niño-Southern Oscillation event: Spatial/temporal patterns and comparisons with the 1982-1983 event, Bull. Mar. Sci., 69, 79-109, 2001.

Goldberg, W. M.: The biology of reefs and reef organisms, University of Chicago Press, Chicago, Illinois, USA, 2013.

Grossman, E. E. and Fletcher III, C. H.: Holocene reef development where wave energy reduces accommodation space, Kailua Bay, windward Oahu, Hawaii, USA, J. Sed. Res., 74, 49-63, 2004.

Guzmán, H. and Cortés, J.: Changes in reef community structure after fifteen years of natural disturbances in the eastern Pacific (Costa Rica), Bull. Mar. Sci., 69, 133-149, 2001.

Hamanaka, N., Kan, H., Yokoyama, Y., Okamoto, T., Nakashima, Y., and Kawana, T.: Disturbances with hiatuses in highlatitude coral reef growth during the Holocene: correlation with millennial-scale global climate change, Global Planet. Change, 80, 21-35, 2012.

Hansen, J., Ruedy, R., Glascoe, J., and Sato, M.: GISS analysis of surface temperature change, J. Geophys. Res., 107, 3099731022, 1999.

Haug, G. H., Hughen, K. A., Sigman, D. M., Peterson, L. C., and Röhl, U.: Southward migration of the Intertropical Convergence Zone through the Holocene, Science, 293, 1304-1308, 2001.

Hoegh-Guldberg, O.: Climate change, coral bleaching and the future of the world's coral reefs, Mar. Freshw. Res., 50, 839-866, 1999.

Hughes, T. P., Anderson, K. D., Connolly, S. R., Heron, S. F., Kerry, J. T., Lough, J. M., Baird, A. H., Baum, J. K., Berumen, M. L., Bridge, T. C., and Claar, D. C.: Spatial and temporal patterns of mass bleaching of corals in the Anthropocene, Science, 359, 8083, 2018.

Jackson, J. B. C.: Pleistocene perspectives of coral reef community structure, Am. Zool., 32, 719-731, 1992.

Johnsen, S. J., Dahl-Jensen, D., Gundestrup, N., Steffensen, J. P., Clausen, H. B., Miller, H., Masson-Delmotte, V., Sveinbjörnsdottir, A. E., and White, J.: Oxygen isotope and palaeotemperature records from six Greenland ice-core stations: Camp Century, Dye-3, GRIP, GISP2, Renland and NorthGRIP, J. Quaternary Sci., 16, 299-307, 2001.

Karamperidou, C., Di Nezio, P. N., Timmermann, A., Jin, F.-F., and Cobb, K. M.: The response of ENSO flavors to mid-Holocene climate: implications for proxy interpretation, Paleoceanography, 30, 527-547, 2015.

Karl, T. R., Knight, R. W., and Baker, B.: The record breaking global temperatures of 1997 and 1998: evidence for an increase in the rate of global warming?, Geophys. Res. Lett., 27, 719-722, 2000.

Kemp, D. W., Colella, M. A., Bartlett, L. A., Ruzicka, R. R., Porter, J. W., and Fitt, W. K.: Life after cold death: reef coral and coral reef responses to the 2010 cold water anomaly in the Florida Keys, Ecosphere, 7, e01373, https://doi.org/10.1002/ecs2.1373, 2016.

Kleypas, J. A., Buddemeier, R. W., Archer, D., Gattuso, J.-P., Langdon, C., and Opdyke, B. N.: Geochemical consequences of increased atmospheric carbon dioxide on coral reefs, Science, 284, 118-120, 1999.

Koutavas, A. and Joanides, S.: El Niño-Southern Oscillation extrema in the Holocene and Last Glacial Maximum, Paleoceanography, 27, PA4208, https://doi.org/10.1029/2012PA002378, 2012.

Koutavas, A., deMenocal, P. B., Olive, G. C., and Lynch-Stieglitz, J.: Mid-Holocene El Niño-Southern Oscillation (ENSO) attenuation revealed by individual foraminifera in eastern tropical $\mathrm{Pa}$ cific sediments, Geology, 34, 993-996, 2006.

Leonard, N. D., Zhao, J.-X., Welsh, K. J., Feng, Y.-X., Smithers, S. G., Pandolfi, J. M., and Clark, T. R.: Holocene sea level instability in the southern Great Barrier Reef, Australia: high-precision U-Th dating of fossil microatolls, Coral Reefs, 35, 625-639, 2016a.

Leonard, N. D., Welsh, K. J., Lough, J. M., Feng, Y.X., Pandolfi, J. M., Clark, T. R., and Zhao, J.-X.: Evidence of reduced mid-Holocene ENSO variance on the Great Barrier Reef, Australia, Paleoceanography, 31, PA002967, https://doi.org/10.1002/2016PA002967, 2016b.

Li, C.-H., Li, Y.-X., Zheng, Y.-F., Yu, S.-Y., Tang, L.-Y., Li, B.B., and Cui, Q.-Y.: A high-resolution pollen record from East China reveals large climate variability near the NorthgrippianMeghalayan boundary (around 4200 years ago) exerted societal influennce, Palaeogeogr. Palaeocl., 512, 156-165, 2018.

Lirman, D., Schopmeyer, S., Manzello, D., Gramer, L. J., Precht, W. F., Muller-Karger, F., Banks, K., Barnes, B., Bartels, E., Bourque, A., Byrne, J., Donahue, S., Duquesnel, J., Fisher, L., Gilliam, D., Hendee, J., Johnson, M., Maxwell, K., McDevitt, E., Monty, J., Rueda, D., Ruzicka, R., and Thanner, S.: Severe 2010 cold-water event caused unprecedented mortality to corals of the Florida reef tract and reversed previous survivorship patterns, PLoS ONE, 6, e23047, https://doi.org/10.1371/journal.pone.0023047, 2011.

Liu, Z., Kutzbach, J., and Wu, L.: Modeling climate shift of El Nino variability in the Holocene, Geophys. Res. Lett., 27, 2265-2268, 2000.

Liu, Z., Lu, Z., Wen, X., Otto-Bliesner, B. L., Timmermann, A., and Cobb, K. M.: Evolution and forcing mechanisms of El Niño over the past 21,000 years, Nature, 515, 550-553, 2014.

Lybolt, M., Neil, D., Zhao, J., Feng, Y., Yu, K.-F., and Pandolfi, J.: Instability in a marginal coral reef: the shift from natural variability to a human-dominated seascape, Front. Ecol. Environ., 9, 154-160, 2011.

Macintyre, I. G.: Demise, regeneration, and survival of some western Atlantic reefs during the Holocene transgression, in: Geological approaches to coral reef ecology, edited by: Aronson, R. B., Springer, New York, NY, 181-200, 2007.

Macintyre, I. G. and Glynn, P. W.: Upper limit of El Niño killoff, Coral Reefs, 9, p. 92, 1990. 
Macintyre, I. G., Glynn, P. W., and Cortés, J.: Holocene reef history in the eastern Pacific: mainland Costa Rica, Caño Island, Cocos Island, and Galápagos Islands, Proc. 7th Int. Coral Reef Symp., Guam 2, 1174-1184, 1992.

Marchant, R. and Hooghiemstra, H.: Rapid environmental change in African and South American tropics around 4000 years before present: a review, Earth-Sci. Rev., 66, 217-260, 2004.

Marcott, S. A., Shakun, J. D., Clark, P. U., and Mix, A. C.: A reconstruction of regional and global temperature for the past 11,300 years, Science, 339, 1198-1201, 2013.

Mayewski, P. A., Rohling, E. E., Stager, J. C., Karlén, W., Maasch, K. A., Meeker, L. D., Meyerson, E. A., Gasse, F., van Kreveld, S., Holmgren, K., and Lee-Thorp, J.: Holocene climate variability, Quaternary Res., 62, 243-255, 2004.

McGregor, H. V. and Gagan, M. K.: Western Pacific coral $\delta^{18} \mathrm{O}$ records of anomalous Holocene variability in the El Niño-Southern Oscillation, Geophys. Res. Lett., 31, L11204, https://doi.org/10.1029/2004GL019972, 2004.

McGregor, H. V., Fischer, M. J., Gagan, M. K., Fink, D., Phipps, S. J., Wong, H., and Woodroffe, C. D.: A weak El Niño/Southern Oscillation with delayed seasonal growth around 4,300 years ago, Nat. Geosci., 6, 949-953, 2013.

McPhaden, M. J., Zebiak, S. E., and Glantz, M. H.: ENSO as an integrating concept in earth science, Science, 314, 1740-1745, 2006.

Menounos, B., Clague, J. J., Osborn, G., Luckman, B. H., Lakeman, T. R., and Minkus, R.: Western Canadian glaciers advance in concert with climate change circa $4.2 \mathrm{ka}$, Geophys. Res. Lett., 35, GL033172, https://doi.org/10.1029/2008GL033172, 2008.

Moy, C. M., Seltzer, G. O., Rodbell, D. T., and Anderson, D. M.: Variability of El Niño/Southern Oscillation activity at millennial timescales during the Holocene epoch, Nature, 420, 162-165, 2002.

Muscatine, L. and Porter, J. W.: Reef corals: mutualistic symbioses adapted to nutrient-poor environments, Bioscience, 27, 454-460, 1977.

Neumann, C. J., Jarvinen, B. R., McAdie, C. J., and Hammer, G. R.: Tropical cyclones of the North Atlantic Ocean, 1871-1998, NOAA National Climatic Data Center, Asheville, North Carolina, 1999.

Perry, C. T., Smithers, S. G., Gulliver, P., and Browne, N. K.: Evidence of very rapid reef accretion and reef growth under high turbidity and terrigenous sedimentation, Geology, 40, 719-722, 2012.

Precht, W. F. and Aronson, R. B.: Climate flickers and range shifts of reef corals, Front. Ecol. Environ., 2, 307-314, 2004.

Rasmussen, S. O., Andersen, K. K., Svensson, A. M., Steffensen, J. P., Vinther, B. M., Clausen, H. B., SiggaardAndersen, M. L., Johnsen, S. J., Larsen, L. B., Dahl-Jensen, D., and Bigler, M.: A new Greenland ice core chronology for the last glacial termination, J. Geophys. Res.-Atmos., 111, https://doi.org/10.1029/2005JD006079, 2006.

Reaka-Kudla, M. L., Feingold, J. S., and Glynn, P. W.: Experimental studies of rapid bioerosion of coral reefs in the Galápagos Islands, Coral Reefs, 15, 101-107, 1996.

Rein, B., Lückge, A., Reinhardt, L., Sirocko, F., Wolf, A., and Dullo, W.-C.: El Niño variability off Peru during the last 20,000 years, Paleoceanography, 20, PA4003, https://doi.org/10.1029/2004PA001099, 2005.
Richmond, R. H.: Energetic relationships and biogeographical differences among fecundity, growth and reproduction in the reef coral Pocillopora damicornis, Bull. Mar. Sci., 41, 594-604, 1987.

Richmond, R. H.: The effects of the El Niño/Southern Oscillation on the dispersal of corals and other marine organisms, in: Global ecological consequences of the 1982-83 El Niño-Southern Oscillation, edited by: Glynn, P. W., Elsevier, Amsterdam, 127-140, 1990.

Riegl, B. and Piller, W. E.: Possible refugia for reefs in times of environmental stress, Int. J. Earth Sci., 92, 520-531, 2003.

Rodríguez-Fonseca, B., Suárez-Moreno, R., Ayarzagüena, B., López-Parages, J., Gómara, I., Villamayor, J., Mohino, E., Losada, T., and Castaño-Tierno, A.: A review of ENSO influence on the North Atlantic, A non-stationary signal, Atmosphere, 7, atmos7070087, https://doi.org/10.3390/atmos7070087, 2016.

Romero-Torres, M., Treml, E., Acosta, A., and Paz-García, D. A.: The eastern tropical Pacific coral population connectivity and the role of the Eastern Pacific Barrier, Sci. Rep., 8, 9354, https://doi.org/10.1038/s41598-018-27644-2, 2018.

Rooney, J., Fletcher, C., Grossman, E., Engels, M., and Field, M.: El Niño influence on Holocene reef accretion in Hawai'I, Pac. Sci., 58, 305-324, 2004.

Ryan, E. J., Smithers, S. G., Lewis, S. E., Clark, T. R., and Zhao, J.-X.: The variable influences of sea level, sedimentation and exposure on Holocene reef development over a crossshelf transect, central Great Barrier Reef, Diversity, 10, 110, https://doi.org/10.3390/d10040110, 2018.

Sachs, J. P., Sachse, D., Smittenberg, R. H., Zhang, Z., Battisti, D. S., and Golubic, S.: Southward movement of the Pacific intertropical convergence zone AD 1400-1850, Nat. Geosci., 2, 519-525, 2009.

Sandweiss, D. H., Maasch, K. A., Burger, R. L., Richardson III, J. B., Rollins, H. B., and Clement, A.: Variation in Holocene El Niño frequencies: climate records and cultural consequences in ancient Peru, Geology, 29, 603-606, 2001.

Selvaraj, K., Chen, C.-T. A., and Lou, J.-Y.: Holocene weak summer East Asian monsoon intervals in subtropical Taiwan and their global synchronicity, Clim. Past Discuss., 4, 929-953, https://doi.org/10.5194/cpd-4-929-2008, 2008.

Staubwasser, M., Sirocko, F., Grootes, P. M., and Segl, M.: Climate change at the $4.2 \mathrm{kaBP}$ termination of the Indus valley civilization and Holocene south Asian monsoon variability, Geophys. Res. Lett., 30, GL016822, https://doi.org/10.1029/2002GL016822, 2003.

Stuiver, M., Reimer, P. J., and Reimer, R. W.: CALIB 7.2, available at: http://calib.org, last access: 25 July 2018.

Svendsen, J. I. and Mangerud, J.: Holocene glacial and climatic variations on Spitsbergen, Svalbard, The Holocene, 7, 45-57, 1997.

Takahashi, K., Montecinos, A., Goubanova, K., and Dewitte, B.: ENSO regimes: reinterpreting the canonical and Modoki El Niño, Geophys. Res. Lett., 38, GL10704, https://doi.org/10.1029/2011GL047364, 2011.

Thompson, D. M., Conroy, J. L., Collins, A., Hlohowskyj, S. R., Overpeck, J. T., Riedinger-Whitmore, M., Cole, J. E., Bush, M. B., Whitney, H., Corley, T. L., and Kannan, M. S.: Tropical Pacific climate variability over the last 6000 years as recorded 
in Bainbridge Crater Lake, Galápagos, Paleoceanography, 32, PA003089, https://doi.org/10.1002/2017PA003089, 2017.

Toth, L. T.: Holocene coral-reef development in the tropical eastern Pacific, Florida Inst. Tech. (Doctoral Dissertation), 402 pp., 2013.

Toth, L. T., Aronson, R. B., Vollmer, S. V., Hobbs, J. W., Urrego, D. H., Cheng, H., Enochs, I. C., Combosch, D. J., van Woesik, R., and Macintyre, I. G.: ENSO drove 2500-year collapse of eastern Pacific coral reefs, Science, 337, 81-84, 2012.

Toth, L. T., Aronson, R. B., Cobb, K. M., Cheng, H., Edwards, R. L., Grothe, P. R., and Sayani, H. R.: Climatic and biotic thresholds of coral-reef shutdown, Nat. Clim. Change, 41, 369-374, 2015a.

Toth, L. T., Aronson, R. B., Cheng, H., and Edwards, R. L.: Holocene variability in the intensity of wind-gap upwelling in the tropical eastern Pacific, Paleoceanography, 30, 1113-1131, 2015 b.

Toth, L. T., Aronson, R. B., and Macintyre, I. G.: Holocene reef development in the eastern tropical Pacific, in: Coral Reefs of the Eastern Tropical Pacific: Persistence and Loss in a Dynamic Environment, in: Coral Reefs of the World 8, edited by: Glynn, P. W., Manzello, D. P., and Enochs, I. C., Springer Science + Business Media, Dordrecht, 2017.

Toth, L. T., Kuffner, I. B., Stathakopoulos, A., and Shinn, E. A.: A 3000-year lag between the geological and ecological shutdown of Florida's coral reefs, Glob. Change Biol., 24, 5471-5483, https://doi.org/10.1111/gcb.14389, 2018.

Tudhope, A. W., Chilcott, C. P., McCulloch, M. T., Cook, E. R., Chappell, J., Ellam, R. M., Lea, D. W., Lough, J. M., and Shimmield, G. B.: Variability in the El Niño-Southern Oscillation through a glacial-interglacial cycle, Science, 291, 1511-1517, 2001.

Urban, F. E., Cole, J. E., and Overpeck, J. T.: Influence of mean climate change on climate variability from a 155-year tropical Pacific coral record, Nature, 407, 989-993, 2000.

Vargas-Ángel, B., Zapata, F. A., Hernández, H., and Jiménez, J. M.: Coral and coral reef responses to the 1997-98 El Niño event on the Pacific coast of Colombia, Bull. Mar. Sci., 69, 111-132, 2001.

Walker, M. J., Berkelhammer, M., Björck, S., Cwynar, L. C., Fisher, D. A., Long, A. J., Lowe, J. J., Newnham, R. M., Rasmussen, S. O., and Weiss, H.: Formal subdivision of the Holocene Series/Epoch: a discussion paper by a working group of INTIMATE (Integration of ice-core, marine and terrestrial records) and the subcommission on Quaternary Stratigraphy (International Commission on Stratigraphy), J. Quaternary Sci., 27, 649-659, 2012.

Wang, B., Wu, R., and Li, T.: Atmosphere-warm ocean interaction and its impacts on Asian-Australian monsoon variation, J. Clim., 16, 1195-1211, 2003.
Webster, J. M., Braga, J. C., Humblet, M., Potts, D. C., Iryu, Y., Yokoyama, Y., Fujita, K., Bourillot, R., Esat, T. M., Fallon, S., Thompson, W. G., Thomas, A. L., Kan, H., McGregor, H. V., Hinestrosa, G., Obrochta, S. P., and Lougheed, B. C.: Response of the Great Battier Reef to sea-level and environmental changes over the past 30,000 years, Nat. Geosci., 11, 426-432, 2018.

Weiss, H.: Global megadrought, societal collapse and resilience at 4.2-3.9 ka BP across the Mediterranean and West Asia, Clim. Chang. Cult. Evol. Mag., 24, 62-63, 2016.

Weiss, H., Courty, M. A., Wetterstrom, W., Guichard, F., Senior, L., Meadow, R., and Curnow, A.: The genesis and collapse of third millennium north Mesopotamian civilization, Science, 261, 9951004, 1993.

Wellington, G. M. and Glynn, P. W.: Responses of coral reefs to El Niño/Southern Oscillation sea-warming events, in: Geological approaches to coral reef ecology, edited by: Aronson, R. B., Springer-Verlag, New York, 342-385, 2007.

Wilkinson, C. (Ed.): Status of coral reefs of the world: 2000, Australian Institute of Marine Science, Cape Ferguson and Dampier, 2000.

Wood, S., Baums, I. B., Paris, C. B., Ridgwell, A., Kessler, W. S., and Hendy, E. J.: El Niño and coral larval dispersal across the eastern Pacific marine barrier, Nat. Commun., 7, 12571, https://doi.org/10.1038/ncomms12571, 2016.

Wu, Q., Zhao, Z., Liu, L., Granger, D. E., Wang, H., Cohen, D. J., Wu, X., Ye, M., Bar-Yosef, O., Lu, B., and Zhang, J.: Outburst flood at 1920 BCE supports historicity of China's Great Flood and the Xia dynasty, Science, 353, 579-582, 2016.

Xiao, J., Zhang, S., Fan, J., Wen, R., Zhai, D., Tian, Z., and Jiang, D.: The 4.2 ka BP event: multi-proxy records from a closed lake in the northern margin of the East Asian summer monsoon, Clim Past, 14, 1417-1425, https://doi.org/10.5194/cp-14-1417-2018, 2018.

Xu, S., Yu, K., Tao, S., Wu, C.-C., Wang, Y., Jiang, W., Wang, S., and Shen, C.-C.: Evidence for the thermal bleaching of Porites corals from 4.0 ka B.P. in the northern South China Sea, J. Geophys. Res.-Biogeo., 123, 79-94, 2018.

Yamano, H., Sugihara, K., Watanabe, T., Shimamura, M., and Hyeong, K.: Coral reefs at $34^{\circ} \mathrm{N}$, Japan: Exploring the end of environmental gradients, Geology, 40, 835-838, 2012.

Zheng, W., Braconnot, P., Guilyardi, E., Merkel, U., and Yu, Y.: ENSO at $6 \mathrm{ka}$ and $21 \mathrm{ka}$ from ocean-atmosphere coupled model simulations, Clim. Dynam., 3, 745-762, 2008. 